\title{
Tourism Value Chain Activities Model for Competitive Advantage Measurement
}

\author{
Filda Rahmiati \\ School of Business \\ President University \\ Cikarang, Indonesia \\ filda.rahmiati@president.ac.id \\ Togar Simatupang \\ School of Business and Management \\ Bandung Institute of Technology \\ Bandung, Indonesia \\ togar@sbm-itb.ac.id
}

\author{
Yunita Ismail \\ Environment Engineering Study Program \\ President University \\ Cikarang, Indonesia \\ yunitaismail@president.ac.id \\ Dwi Larso \\ School of Business and Management \\ Bandung Institute of Technology \\ Bandung, Indonesia \\ dwilarso@sbm-itb.ac.id
}

\author{
Grace Amin \\ School of Business \\ President University \\ Cikarang, Indonesia \\ grace_amin@president.ac.id \\ Norfaridatul Akmaliah Othman \\ Faculty of Technology Management \\ and Technopreneurship \\ Universiti Teknikal Malaysia Melaka \\ Melaka, Malaysia \\ norfaridatul@utem.edu.my
}

\begin{abstract}
Tourism characterized as an industry with a strong competition. Therefore, it is crucial to create a competitive advantage in order to stay in the market. In the case of the tourism industry, creating competitive advantage could be done by providing an extraordinary experience which is the ultimate goal for travel leading to customer satisfaction and customer loyalty. This paper aims at exploring and developing a model of tourism value chain activities experience by tourist for competitive advantage creation. Tourism value chain activities model consists of three stages whereby each stage has its own type of measurement. The first stage covers the pre-trip experience, in this stage, the detailed information prior to departure will be discussed. Next stage is the trip experience, which are the tourism activities involved during the visit and experienced during the trip. Lastly the post-trip experience, whereby on this stage the output of the tourism value chain activities will be measured. The proposed measurement for this stage will be an evaluation of tourist satisfaction and tourist loyalty in order to create a competitive advantage. Future studies are expected in implementing these tourism value chain activities in specific tourism destinations (country) to measure the tourism experience.
\end{abstract}

Keywords-tourism, competitive advantage, travel experience, tourism value chain activities

\section{INTRODUCTION}

Tourism industry is quantified as one of the world's rapidly rising economic sectors worldwide [1]. The contribution is vital by driving growth, reducing poverty, fostering development and tolerance, as well as creating employment opportunities [2], [3]. Therefore, tourism service providers should develop competitive advantage in order to stay in the market [4]. Extraordinary experience is the ultimate goal for travel in tourism industry, hence, countries and tourism service providers should facilitate distinct travel experience to increase competitiveness in order to stand out among competitors [5], [6]. This will lead to customer satisfaction and customer loyalty [7], [8].

The travel experience consists of a series of activities experienced by tourist provided by multiple different entities such as air carriers, hotels, restaurants, and tours. In facilitating a distinct travel experience, tourism industry requires tourism service providers to collaborate, coordinate, and integrate into creating the best tourism

Funded by Directorate of Research and Community Service. Directorate General of Strengthening Research and Development. Ministry of Research, Technology, and Higher Education year 2019 products and services [9] as customers always change in demand and consumption pattern [2]. In the tourism industry, understanding the customer's behavior enables tourism players to serve tourist better and more efficient in the competitive market [10]. Hence, to get successful collaboration and cooperation along the value chain, focusing on the customer is crucial [11]-[13]. It is necessary for creating value through all activities in travel experience aim in gaining competitive advantage which called tourism value chain activities.

Tourism value chain activities refer to a series of interrelated activities which create values that are experienced by tourists during their trip. In the tourism value chain, it requires all players to work together in adding value for delivering product and services to tourists called as "customer centricity" [13], [14] or customer experience value chain [15]. Tourist experience in value chain details the steps that tourists decide when going on a vacation until they return back from the journey. The interdependence feature of tourism industry players makes them heavily reliant on each other; sharing and appreciating the long-term interests and environment, and estimating the unexpected events [16], [17]. Value chain activities, hence, is a discrete building block of competitive advantage [18].

Previous studies discussed tourism value chain on the supply side of tourism industry, which are the players in tourism industry [19]-[23] consists of many entities, such as organizational ownership and operational business structures [2], small enterprises industries [24], and economic flow and sustainable development [17]. Furthermore, previous research that analyzes tourist experience explaining on tourism value chain activities is still limited. Past studies focused only on the promotional area of tourism [25] and branding of destination [5]. Hence, although there are many studies that have analyzed tourist experience [26]-[29], none of them links to tourism value chain activities. It suggests that the study of tourism value chain activities from the customer (tourist) is crucial also vital for countries and tourism service providers [9]. Therefore, this paper aims at exploring and developing a model of tourism value chain activities experience by tourist for competitive advantage creation. 


\section{LITERATURE REVIEW}

\section{A. Competitive Advantage}

In the case of tourism, the main goals of travel is an extraordinary experience [5] whereby competitive advantage totally depends on each tourism players ability to facilitate the best travel experience. Therefore, countries and destinations should facilitate distinct travel experience to increase their competitiveness to make them stand out among their competitors. Research study of tourism found that in measuring intention for revisit in the future, service performance (in terms of quality) enhanced by satisfaction are strongly connected which lead to customer loyalty. Therefore, ways to achieve competitive advantage could be through identifying the tourist satisfaction and tourist loyalty. This paper will explain further on how tourist satisfaction and tourist loyalty formed competitive advantage.

In the case of the tourism industry, providing an extraordinary experience which is the ultimate goal for travel - to make them outperform their competitors and to lead to customer satisfaction and customer loyalty. Customer satisfaction can provide major competitive advantage [30], which can directly lead to an increase in profitability and growth. Further, conclude that providing good service quality ensures satisfaction from customer and increases a propensity of revisit, and those interrelated processes could able to create a competitive advantage [25].

Many studies in the tourism context used tourist loyalty as an outcome where it is affected positively by tourist satisfaction. When customer satisfaction increases, it leads to the intention to return and recommend to other rises, whereby it is significant for customer loyalty [25], [31]-[33]. Further, customer loyalty drives to continue to use the same product or service, able to reduce cost of promotional, and decrease the price sensitivity[3]. Loyal customers purchase from the business they are loyal to more often than non-loyal customers. They also purchase a broader variety of items. Loyal customers are less likely to switch because of price. Further, loyal customers make more purchases than the nonloyal customers. To conclude, customer loyalty could be mentioned as the customer who have long term commitment to the company to keep buying or consuming the company's product or service regardless the price. Furthermore, as a satisfied customer, they tends to recommend the product or service to others [34]. It was highlighted that the more satisfied and loyal a tourist is, they could impact to the positive word of mouth publication (WOM) and thus said to be the most influential in the purchasing decision for the prospectus tourist [35]. Tourist loyalty could be formed by many ways such as revisiting, recommendation, and positive word of mouth publication.

\section{B. Travel Experience}

Organization's capabilities in competing to provide extraordinary experience to reach competitive advantage are crucial. Supported by the involvement of customer feedback, it could help in improving tourism product/service. The main important point is understanding the customer needs [36], [37]. Perceived service value in the tourism context could be in the pre-trip, during the trip, or even after the trip [25], [38]. Cumulative values experienced by tourist build customer loyalty after feeling satisfaction of the trip [39]. Specifically, realizing the customer perspective in the travel experience is valuable on to the contribution of the knowledge also drivers supports of tourism players in managing destination as a valuable asset for attracting next arrivals and providing revenues from tourist expenditure [5].

The primary goals for tourism industry are creating competitive advantage through creating an extraordinary travel experience from a tourist perspective helping destinations managers' evaluation for future arrivals and expenditures. Therefore, to analyze travel experience, manage and measure the whole value chain, focusing on customer's need is important [9].

\section{Tourism Value Chain}

The powerful Porters' Value Chain model is still applicable until current research that is applied in the tourism context [6], [9], [19], [21], [40]-[44]. Measuring the value chain in the tourism industry is important as it benefited in terms of effectiveness and efficiency to various stakeholders along the chain.

Applying tourism value chain activities from original value chain activities should have some modification [43]. Therefore, Porter's original value chain applied for tourism industry must be converted from the manufacturing sector into the service sector. Tourism value chain shows number of sources of competitive advantage from the ability to create and effectively manage all players in tourism industry, supported by the ability of local governance to guarantee to push the attractiveness of the area and to differentiate it from competitors [45]. It is important for all tourism players in tourism chain to work together in order to create value along the value chain in order to deliver satisfied tourism product and services [46].

Studies regarding Tourism Value Chain have been done earlier which mostly focus on the supply side of tourism and using qualitative method of analysis. Most of the studies were analyzing cities in order to enhance tourism destinations for supporting government performance in order to increase tourism revenue [6], [21]-[24], [43], [47]. Meanwhile, an insight about the travel experience value chain which consist of pre-consumption phase, consumption phase, and post-consumption phase [5]. A paper proposing a value chain framework for analyzing travel experience, proposed a tourism value chain which suggests to analyze the evaluation of tourism value chain activities for both tourist and tourism suppliers to reach satisfaction regarding tourist experience [9] .

Nonetheless, there have been little further studies to conduct Value Chain Activities for each activity in the value chain model. Therefore, this study tries to implement the value chain activities model which have not implemented in the past. Next will be discussed the detail of tourism value chain activities which also connected to how it can lead to a competitive advantage.

\section{A Model of Tourism VAlue Chain Activities FOR COMPETITIVE ADVANTAGE}

\section{A. Development of the Model}

The model has been built by compiling many previous studies related to the topic in building the theoretical 
background of the research. The basis of the term "model" is formed from a conceptual framework [48]. When a conceptual framework consists of variables or factors is used in the study, then it is called as a "model". Hence, this study uses the term "model" to be more appropriate. The first step, the key concepts were defined. The key concepts explain the general and compact definition of a phenomenon which is essential for scientific research for measurement the phenomenon [49]. Next, the background in creating the model was developed by examining and matching the existing literature of value chain activity and competitive advantage.

A model in this case, is a connecting all elements which is related to the study. In conclusion, the features of a model can be defined as an interpretative approach to social case. It provides deep understanding of intentions. Also, can be construct though a process of qualitative way although generated from many sources, it seeks to generate new interpretation in a particular field of study.

Finally, this study makes effort to explore the tourism value chain activities model consisting of three stages whereby each stage has its own type of measurement. The first stage covers the pre-trip experience, where in this stage it will discuss the detailed information prior to departure. Next stage is the trip experience, that is the tourism activities involved during the visit and experienced during the trip. The last is the post-trip experience, whereby on this stage the output of the tourism value chain activities will be measured. The proposed measurement for this stage will be an evaluation of tourist satisfaction and tourist loyalty in order to create a competitive advantage.

\section{B. Description of the Model}

The developed model is presented in Figure 1. Through the analysis of previous studies, three stages of tourism value chain activities were formed.

\section{1) Pre-trip Experience}

In the pre-trip experience, tourists search as much information regarding the travel destination and ends with the traveler's assessment after consuming the experience [5]. In this stage, tourists will have alternatives before they decide which tourism product will be chosen. Therefore, information search related to tourism destination will be paramount in this stage as a contribution to the decision making of their vacation. Information service quality is crucial in the pre-trip experience in order to quantify the satisfaction of the tourists [50]. Giving the detailed and accurate information from the pre-trip activities about the destinations and other things that tourists may need before departure is important [9], [13].

Another important thing during the pre-trip experience is to get to know the tourist product availability. In planning their vacation, tourists can ask for help from tour agency or they can arrange it personally with the help of internet technology in booking their trip. Next, the pre-trip activities consist of activities of preparing documents before vacation, for example, visa requirements. This stage is called an international process of tourism activities. Once a tourist is interested in the tourism products available, they can create the intention to visit the tourism destination and start on planning the holiday vacation.

\section{2) Trip Experience}

The trip experience stage is where the customers consume the tourism products such as transportation inbound and outbound, accommodation during the trip, and many tourism activities named as excursions. First subsector is transportation which is divided by international transport and national transport. The most common international transport mode is international air carriers [51], but nowadays a cruise by land is also available. There is also local transport based in the inbound country. Inbound countries have their own transportation actors and often have coordination and cooperation with international distribution firms. Accommodation could be seen a place to stay.

This stage explains about various types of accommodations such as hotels, boutique hotels, motels, apartments, and resort. Lastly, excursions activities will be experienced by tourists. Excursions are natural tourism, entertainment, festival, and also shopping. Further, tourist's experience occurred when the tourist is involved in the tourism activities during the trip either by consuming tourism products or services. Those activities could be purchasing tangible products such as souvenirs, foods and drinks. Even during consuming tourism services such as staying in the hotels, consuming the scenery of the natural tourism. Those activities could lead to the intention of revisit. By providing the best tourism products and services, this leads to positive referrals which enhanced loyalty [27].

Service quality, whereby many studies focus on the five dimensions of SERVQUAL might be unmatched if a study about tourism as tourism industry is focusing more on services. Tourism industry has its own uniqueness where many players join together in order to serve a tourist (customer) such as hotel, restaurant, travel agency, and others. As a consequence, service quality offered during the trip experiences in tourism should be carefully considered and modified to meet the tourist's needs using TourServQual [37].

Previous study has been done on tourism service quality investigated accommodation service quality, hospitality, entertainment and transportation, and taxi service quality, which are aimed for overall satisfaction, intention to revisit, and willingness to recommend to relatives and friends [52]. In addition, another study analyses the service quality dimensions that influence satisfaction and future intentions to return. In this case, service quality is important for achieving competitive advantage. Based on mentioned above, this study tries to analyze tourism value chain activities based on tourist perspective for the trip experience using service quality which will be segregated based on each activity such as transportation, accommodations, and excursions [86].

\section{3) Post-trip Experience}

During this stage, the assessment will be done by tourist to measure the performance for the tourism destination in order to create the competitive advantage by measuring their satisfaction and loyalty. Post-trip experience stage is where the tourist assesses the tourism experience. In this stage, customer survey measured the whole tourism activities along the chain from the pre-trip stage, trip stage, 
and last the satisfaction and loyalty measurement in the post trip experience stage.

A proposed model of tourism value chain activities tries to explore the suitability of the tourism value chain activities based on tourist experience is benefited. Analyze tourism value chain activities based on tourist perspective could be examined by tourism product availability and service quality (in terms of information service quality, tourism products and services service quality). Understanding Tourism Value Chain from a customer perspective is a valuable contribution in creating a value aimed for competitive advantage.

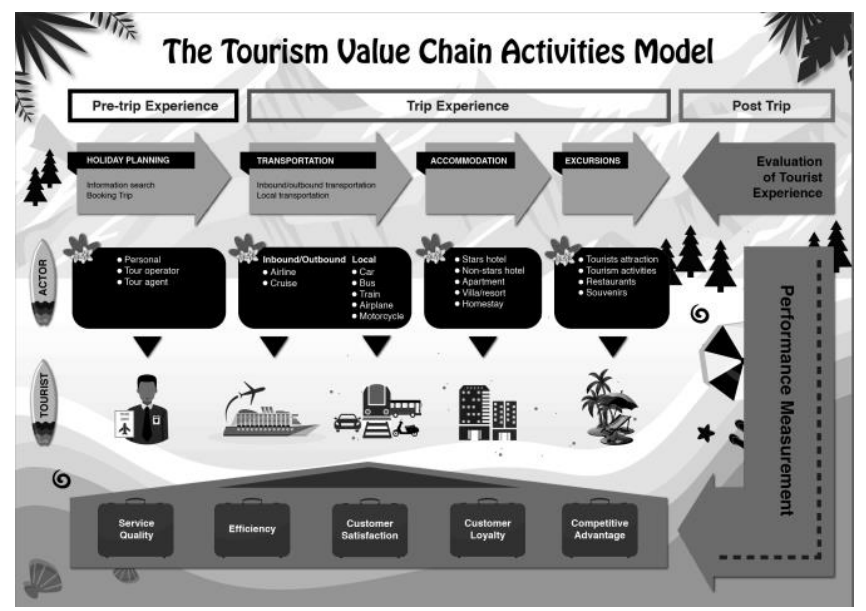

Fig. 1 The Tourism Value Chain Activities Model

\section{CONCLUSION}

This study is intended to form the model of Tourism Value Chain Activities without analyzing it in any case studies. Since the model is formed from previous studies, there is a possibility to have differences when it is applied to a specific tourism destination or country. Therefore, future studies are expected to investigate the implementation of these tourism value chain activities in any specific tourism destination (country) to measure the tourism experience. Based on the 2017 Annual Economic Reports for the World Travel \& Tourism Council (WTTC) stated that the strongest growth in 2016 was in Southeast Asia (8.3\%) with the fastest growing travel \& tourism countries are expected to be China, India, Thailand, and Indonesia [53]. Therefore, it is expected to further study the relevant conditions in the countries mentioned above, since clearer findings will be available when a study is applied specifically.

\section{REFERENCES}

[1] Deloitte, "2018 travel and hospitality industry outlook," 2018.

[2] M. Christian, K. Fernandez-Stark, G. Ahmed, and G. Gereffi, "The Tourism Global Value Chain: Economic Upgrading and Workforce Development," 2011.

[3] P. Kotler, J. T. Bowen, J. C. Makens, and S. Baloglu, Marketing for Hospitality and Tourism, 7th Editio. Boston: Pearson Education, 2017.

[4] P. Y. Yang, L. Luo, C. J. Li, Y. Yang, and S. H. T. Lee, "The rise of the manufacturing service industry: the perspective of value-added chain model," Chinese Manag. Stud., vol. 7, no. 3, pp. 403-418, 2013

[5] M. S. Nikolova, "Towards a Travel Experience Value Chain as a Tourism Destination Management Tool," in Proceeding of the Travel and Tourism Research Association, 2008, pp. 401-425.
[6] B. Mete and E. Acuner, "A Value Chain Analysis of Turkish Tourism Sector," Int. J. Bus. Manag. Stud., vol. 03, no. 2, pp. 499-506, 2014.

[7] T. Hennig-Thurau and U. Hansen, Relationship Marketing: Gaining Competitive Advantage through Customer Satisfaction and Customer Retention. New York: Springer Science \& Business Media, 2013.

[8] P. Wathigo, "The Effect of Loyalty Programs on Customer Loyalty in Nairobi County," 2016

[9] Y. Yilmaz and U. S. Bititci, "Performance measurement in tourism: A value chain model," Int. J. Contemp. Hosp. Manag., vol. 18, no. 4 , pp. 341-349, 2006.

[10] D. G. Pearce and C. Schott, "Tourism Distribution Channels: The Visitors' Perspective," J. Travel Res., vol. 44, no. August, pp. 50-63, 2005.

[11] A. Fearne, M. Garcia Martinez, and B. Dent, "Dimensions of Sustainable Value Chains: Implications for Value Chain Analysis," Supply Chain Manag. An Int. J., vol. 17, no. 6, pp. 575-581, 2012.

[12] D. Palacios-Marques, M. Guijarro, and A. Carrilero, "The use of customer-centric philosophy in hotels to improve customer loyalty," J. Bus. Ind. Mark., vol. 31, no. 3, pp. 339-348, 2016.

[13] A. Yahya, "Kemenpar Menuju Customer-Centric Organization," 2017. [Online]. Available:

http://www.kemenpar.go.id/asp/detil.asp?c=193\&id=3526 [Accessed: 13-May-2017].

[14] K. Navakiran, "Companies that adopt a customer-centric value chain will gain a sustainable competitive advantage.," Teletech, 2010.

[15] M. Hinshaw, "The 'Secret' To CX Success_ The Customer Experience Value Chain," CMO, 2017.

[16] T. M. Simatupang, P. Piboonrungroj, and S. J. Williams, "The emergence of value chain thinking," Int. J. Value Chain Manag., vol. 8 , no. 1 , p. 40,2017

[17] F. Vignati and Q. Laumans, "Value Chain Analysis as a Kick Off for Tourism Destination Development in Maputo City.," Int. Conf. Sustain. Tour. Dev. Ctries., pp. 1-13, 2010.

[18] M. E. Porter, Competitive Advantage: Creating and Sustaining Superior Performance. Free Press, 1998.

[19] N. C. Curta, "Customize The Value Chain for Tourism Companies," Quaestus Multidiscip. Res. J., pp. 75-85, Feb. 2014.

[20] International Finance Corporation \& The World Bank, "The Tourism Sector in Mozambique: A Value Chain Analysis," 2006.

[21] V. B. Laiskodat, D. D. Kameo, and I. Utami, "The Value Chain of Tourism at Komodo Island of Indonesia," in 5th Asian Business Workshop and Conference, 2017, pp. 74-82.

[22] B. Steck, K. Wood, and J. Bishop, "Tourism: More value for Zanzibar - Value chain analysis," no. February 2010, 2010

[23] D. Yusri, A. Daryanto, and H. K. Purwadaria, "The Study of Bogor Botanical Garden Ecotourism Value Chain," J. Manaj. Agribisnis, vol. 9, pp. 19-25, 2012.

[24] D. Mcewen and O. Bennett, "Seychelles Tourism Value," Seychelles, 2010

[25] H.-C. Liang, "Impact of Logistics Service Performance on Tourist Satisfaction and Loyalty," RMIT University, 2008.

[26] A. Akhoondnejad, "Analyzing the Pre-Travel, On-Travel, and PostTravel Behaviors of Iran's First-Time Visitors," J. Travel Tour. Mark., vol. 32, no. 8, pp. 1023-1033, 2015.

[27] J. Da Costa Mendes, P. O. Do Valle, M. M. Guerreiro, and J. A. Silva, "The tourist experience: Exploring the relationship between tourist satisfaction and destination loyalty," 2010.

[28] M. Gallarza, F. Arteaga, G. Del Chiappa, I. Gil-Saura, and M. Holbrook, "A multidimensional service-value scale based on Holbrook's typology of customer value: bridging the gap between the concept and its measurement," J. Serv. Manag., vol. 28, no. 4, pp. 724-762, Jul. 2017.

[29] B. Roy, A. Mamun, and B. C. Kuri, "Sustainable Tourism Supply Chain Management for Tourism Industry in Bangladesh," Glob. J. Manag. Bus. Res., vol. 15, no. 2, pp. 19-26, 2015.

[30] J. N. Sheth, Competitive Advantages Through Customer Satisfaction, vol. 2. 2001.

[31] Wahyuningsih, "The Effect of Customer Value on Behavioral Intentions in Tourism Industry," Int. Res. J. Bus. Stud., vol. 5, no. 1, 2012 
[32] F. Amoah, L. Radder, M. van Eyk, and M. van Eyk, "Perceived experience value, satisfaction and behavioural intentions: A guesthouse experience," African J. Econ. Manag. Stud., vol. 7, no. 3, pp. 419-433, 2016.

[33] W. Chiu, S. Zeng, and P. S. T. Cheng, "The influence of destination image and tourist satisfaction on tourist loyalty: a case study of Chinese tourists in Korea," Int. J. Cult. Tour. Hosp. Res., vol. 10, no. 2, pp. 223-234, 2016.

[34] L. Xue and C. Yang, "An Exploratory Study of Customer Satisfaction Based on ACSI Model," 2008.

[35] W. K. A. Gnanapala, "Tourists Perception and Satisfaction: Implications for Destination Management," Am. J. Mark. Res., vol. 1, no. 1, pp. 7-19, 2015.

[36] R. B. Woodruff, "Customer Value: The Next Source for Competitive Advantage," J. Acad. Mark. Sci., vol. 25, no. 2, pp. 139-153, 1997.

[37] M. I. Eraqi, “Tourism services quality (TourServQual) in Egypt: The viewpoints of external and internal customers," Benchmarking An Int. J., vol. 13, no. 4, pp. 469-492, 2006.

[38] A. B. Danurdara and N. Hidayah, "Creating Customer Value and Its Implication To Customer Loyalty: An Empirical Study at Star Hotels in West Java, Indonesia," Int. Rev. Manag. Bus. Res., vol. 5, no. 2, pp. 732-742, 2016.

[39] K. S. Ying, A. Jusoh, and Z. Khalifah, "A Conceptual Model of Tourist Satisfacton," Pertanika J. Soc. Sci. Humanit., vol. 24, no. 1, pp. 505-518, 2016.

[40] S. C. Dong and C. M. Hwy, From Adam Smith to Michael Porter Evolution of Competitiveness Theory. World Scientific Publishing, 2002.

[41] P. Ensign, "Value Chain Analysis and Competitive Advantage," $J$. Gen. Manag., vol. 27, no. 1, pp. 18-42, 2001.

[42] A. Martel and W. Klibi, Designing value-creating supply chain networks. 2016
[43] A. Sharma and I. T. Christie, "Performance assessment using valuechain analysis in Mozambique," Int. J. Contemp. Manag., vol. 22, no. 3, pp. 282-299, 2010.

[44] H. Skipworth, J. Godsell, C. Y. Wong, S. Saghiri, and D. Julien, "Supply chain alignment for improved business performance: an empirical study," Supply Chain Manag. An Int. Journal2, vol. 20, no. 5, pp. 511-533, 2015.

[45] C. Mottironi and M. A. Corigliano, "Tourist Destination Competitiveness: The Role Of Cooperation," Riv. Ital. di Econ. Demogr. e Stat., vol. LXVI, no. 2, 2012.

[46] Y. Yilmaz and U. Bititci, "Performance measurement in the value chain: manufacturing v. tourism," Int. J. Product. Perform. Manag., vol. 5, no. 5, pp. 371-389, 2006.

[47] SNV Netherland Development Org, "Value Chain Development for Tourism Destinations," 2010.

[48] Y. Jabareen, "Building a Conceptual Framework: Philosophy , Definitions , and Procedure," pp. 49-62, 2009.

[49] M. Saulina, "Performance measurement approach for innovation capability in SMEs," Int. J. Product. Perform. Manag., vol. 65, no. 3, 2016.

[50] P. Chithambaranathan, N. Subramaniam, and P. L. K. Palaniappan, "An innovative framework for performance analysis of members of supply chains," Benchmarkig An Int. J., vol. 22, no. 2, pp. 309-334, 2015

[51] M. Christian, K. Fernandez-Stark, G. Ahmed, and G. Gereffi, "The Tourism Global Value Chain," Cent. Glob. Gov. Compet, no. November, pp. 1-62, 2011.

[52] K. Latiff and N. S. Imm, "The Impact of Tourism Service Quality on Satisfaction,” Int. J. Econ. Manag., vol. 9, pp. 67-94, 2015.

[53] D. Scowsill, "Travel \& Tourism Global Economic Impact \& Issues $2017, " 2017$. 